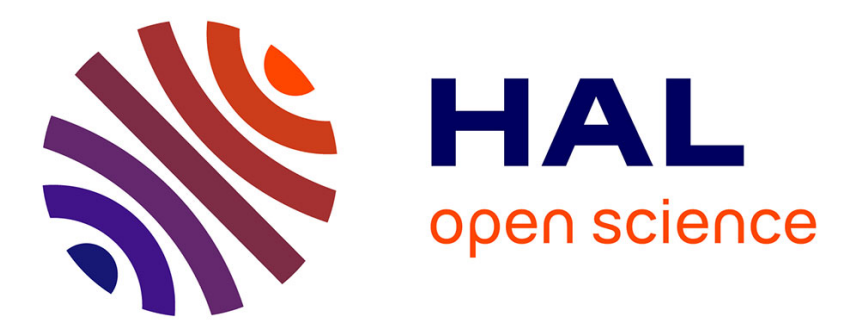

\title{
Stability of microbial communities in goat milk during a lactation year: molecular approaches
}

Cécile Callon, Frédérique Duthoit, Céline Delbès, Marion Ferrand, Yves Le Frileux, Renée de Crémoux, Marie-Christine Montel

\section{- To cite this version:}

Cécile Callon, Frédérique Duthoit, Céline Delbès, Marion Ferrand, Yves Le Frileux, et al.. Stability of microbial communities in goat milk during a lactation year: molecular approaches. Systematic and Applied Microbiology, 2007, 30 (7), pp.547-60. 10.1016/j.syapm.2007.05.004 . hal-00621188

\section{HAL Id: hal-00621188 \\ https://hal.univ-brest.fr/hal-00621188}

Submitted on 31 May 2020

HAL is a multi-disciplinary open access archive for the deposit and dissemination of scientific research documents, whether they are published or not. The documents may come from teaching and research institutions in France or abroad, or from public or private research centers.
L'archive ouverte pluridisciplinaire $\mathbf{H A L}$, est destinée au dépôt et à la diffusion de documents scientifiques de niveau recherche, publiés ou non, émanant des établissements d'enseignement et de recherche français ou étrangers, des laboratoires publics ou privés. 


\title{
Stability of microbial communities in goat milk during a lactation year: Molecular approaches ${ }^{\text {th }}$
}

\author{
Cécile Callon $^{\mathrm{a}, *}$, Frédérique Duthoit ${ }^{\mathrm{b}}$, Céline Delbès ${ }^{\mathrm{a}}$, Marion Ferrand ${ }^{\mathrm{d}}$, \\ Yves Le Frileux ${ }^{\mathrm{c}}$, Renée De Crémoux ${ }^{\mathrm{d}}$, Marie-Christine Montel $^{\mathrm{a}}$ \\ a INRA-Unité de Recherches Fromagères URF545, INRA, 36 Rue de Salers, 15000 Aurillac, France \\ ${ }^{\mathrm{b}}$ Université de Brest, Laboratoire de Microbiologie des Environnements Extrêmes UMR 6197, 29280 Plouzané, France \\ ${ }^{\mathrm{c}}$ Station du Pradel, Ferme Expérimentale Caprine, 07170 Mirabel, France \\ 'Institut de l'Elevage, 142 rue de l'Université, 75595 Paris cedex 12, France
}

Received 7 February 2007

\begin{abstract}
The microbial communities in milks from one herd were evaluated during 1-year of lactation, using molecular methods to evaluate their stability and the effect of breeding conditions on their composition. The diversity of microbial communities was measured using two approaches: molecular identification by $16 \mathrm{~S}$ and 18S rDNA sequencing of isolates from counting media (two milks), and direct identification using 16S rDNA from clone libraries (six milks). The stability of these communities was evaluated by counting on selective media and by Single Strand Conformation Polymorphism (SSCP) analysis of variable region V3 of the 16S rRNA gene and variable region V4 of the 18S rRNA gene. One hundred and eighteen milk samples taken throughout the year were analyzed. Wide diversity among bacteria and yeasts in the milk was revealed. In addition to species commonly encountered in milk, such as Lactococcus lactis, Lactococcus garvieae, Enterococcus faecalis, Lactobacillus casei, Leuconostoc mesenteroides, Staphylococcus epidermidis, Staphylococcus simulans, Staphylococcus caprae, Staphylococcus equorum, Micrococcus sp., Kocuria sp., Pantoea agglomerans and Pseudomonas putida, sequences were affiliated to other species only described in cheeses, such as Corynebacterium variabile, Arthrobacter sp., Brachybacterium paraconglomeratum, Clostridium sp. and Rothia sp. Several halophilic species atypical in milk were found, belonging to Jeotgalicoccus psychrophilus, Salinicoccus sp., Dietza maris, Exiguobacterium, Ornithinicoccus sp. and Hahella chejuensis. The yeast community was composed of Debaryomyces hansenii, Kluyveromyces lactis, Trichosporon beigelii, Rhodotorula glutinis, Rhodotorula minuta, Candida pararugosa, Candida intermedia, Candida inconspicua, Cryptococcus curvatus and Cryptococcus magnus. The analyses of microbial counts and microbial SSCP profiles both distinguished four groups of milks corresponding to four periods defined by season and feeding regime. The microbial community was stable within each period. Milks from winter were characterized by Lactococcus and Pseudomonas, those from summer by $P$. agglomerans and Klebsiella and those from autumn by Chryseobacterium indologenes, Acinetobacter baumanii, Staphylococcus, Corynebacteria and yeasts. However, the composition of the community
\end{abstract}

\footnotetext{
${ }^{25}$ Note: Nucleotide sequence data reported are available in the DDBJ/EMBL/Genbank database under the accession numbers EF588263-EF588274, EF621423-EF621473, EF611741-EF611817, EF627478-EF627522, EF633693.

*Corresponding author. Tel.: + 33471456412 ; fax: + 33471456113 .

E-mail address: callon@clermont.inra.fr (C. Callon).
} 
can vary according to factors other than feeding. This study opens new investigation fields in the field of raw milk microbial ecology.

(C) 2007 Elsevier GmbH. All rights reserved.

Keywords: Microbial communities; Raw goat milk; Molecular methods; Lactation year

\section{Introduction}

Many interacting factors can affect the qualities of goat cheese. The most important are technological parameters, the biochemical composition of the milk and the composition of its microbial communities. Even when the milk is prepared using the same technology, these qualities can vary over a 1-year period. Milk fat composition, for example, can change according to feeding regime and lactation [41]. Variation in the composition of goat milk microbial communities has been less extensively studied. Goat milk and cheese microbial communities have more often been described by enumerating a group of microorganisms on various culture media $[1,7,29,32,39]$. There have been few studies identifying the microorganisms at species level, and these have generally concerned a specific microbial group, mainly lactic acid bacteria [22,27,28,37], Enterobacteriaceae [39,45], Micrococcaceae [21,34,43,46], yeasts $[38,44]$ or pathogenic microorganisms $[16]$. The study by Foshino et al. [16] only focused on the effect of farm and lactation period over a 6-months period. Other studies have described variations during cheese manufacture and ripening $[18,28,37]$ at only three or four different times over the lactation. It would be useful to have a more comprehensive view of the microbial composition of milk, and to track its evolution throughout the lactation.

In the past few years, cultivation-independent methods such as Single Strand Conformation Polymorphism (SSCP), Temperature Gradient Gel Electrophoresis (TGGE) and Denaturing Gradient Gel Electrophoresis (DGGE) have proven to be powerful tools for studying food samples, bringing a more comprehensive and dynamic view of microbial diversity than culturedependent methods $[3,8,12,14]$. They also make it easier to compare different microbial communities such as those present in goat milks at different times during 1-year of lactation.

The aim of our study was to investigate the stability of microbial communities, including bacteria and yeasts, of goat milks used for cheese manufacturing and taken from one herd over 1 lactation year. Two approaches were used: (1) molecular identification of isolates and clones (Restricted Fragment Length Polymorphism (RFLP) and 16S rDNA and 26S rDNA sequencing), and (2) $16 \mathrm{~S}$ rDNA and $18 \mathrm{~S}$ rDNA SSCP analysis for monitoring changes in the microbial community. The impact of feeding regime and other factors on milk microbial composition was studied.

\section{Materials and methods}

\section{Breeding conditions during the lactation year}

Because goat milk production is seasonal, the notion of a "period" is defined by both physiological aspects and seasonal aspects. For herds that are grazed, these aspects are closely related to feeding regime (composition, type, supplementation).

Four periods were defined according to season and the related breeding conditions. The winter period P1 encompasses the milk samples from day 45 through 86 . At this time the milk volume of the herd was more than 4001. There was no outside grazing, the feed was dried alfafa. Outdoor grazing on Graminaceae and dried alfafa characterized the spring period ( $\mathrm{P} 2$; days 87-163) in which the herd yielded 400-5001 milk/day. During the summer period P3 (days 164-269), the milk volume of the herd was 200-4001 and the feed was like in period $\mathrm{P} 1$. The autumn period ( $\mathrm{P} 4$; days $270-330)$ was characterized by the lower milk volume (100-2001) and outdoor grazing on Graminaceae.

\section{Sample collection and treatment}

A total of 118 samples of raw bulk milk $(30 \mathrm{ml})$ were collected between February and November 2005 on an experimental goat farm (Domaine du Pradel, France), at a rate of 3-5 milks per week. Samples were numbered by day of the year (1 for January 1st and so on). Each sample was taken from the refrigerated tank (a mixture of the evening milking refrigerated overnight at $4{ }^{\circ} \mathrm{C}$ and the morning milking) and stored at $-20^{\circ} \mathrm{C}$ before being investigated.

\section{Counts on media and isolate collection}

Ten milliliters of milk were homogenized in $90 \mathrm{ml}$ sterile diluent (solution with $0.8 \% \mathrm{NaCl}, 0.1 \%$ peptone, $0.1 \%$ Tween 80 ) for $2 \mathrm{~min}$ in a Stomacher Laboratory Blender (Interscience, St. Nom la Bretèche, France). The microbial counts of the milks were evaluated on 
different media (two replicates per sample) as described by Millet et al. [30].

The bacterial media used (Table 4) were Plate Count Agar with Gram-positive inhibitor (PCAI), Cheese Ripening Bacteria Medium (CRBM), Terzaghi and Sandine M17, Rabbit Plasma Fibrinogen Agar (RPF), facultatively heterofermentative lactobacilli agar $(\mathrm{FH})$, Slanetz and Bartley (SB), Turner-Sandine-Elliker with nalidixic acid (TA), Mayeux-Sandine-Elliker (MSE), and Cetrimin-Fucidin-cephalosporin (CFC) media plates. All colonies growing on the various media were retrieved from plates of two milks (49 and 151). These two milks were selected as they had they belong to two different periods. Moreover, they had the highest counts and the colonies on different media had the highest morphology's diversity. Two hundred and eighty-one bacterial isolates were purified and stored at $-20{ }^{\circ} \mathrm{C}$ in $50 / 50(\mathrm{v} / \mathrm{v})$ broth and milk with glycerol $(10 \%)$.

All yeast colonies growing on Oxytetracyclin Glucose Agar (OGA) medium from the analysis of six different milks, numbered 72 and 81 (from P1), 168, 181 and 209 (from P3), 280 (from P4), were retrieved. Forty-six isolates were purified and stored at $-20{ }^{\circ} \mathrm{C}$ in $50 / 50(\mathrm{v} / \mathrm{v})$ Yeast Peptone Glucose broth and milk with glycerol $(10 \%)$.

\section{Bacteria identification}

The identification of bacteria was solely based on $16 \mathrm{~S}$ rRNA sequence comparison.

\section{Total DNA extraction}

Total DNA from bacterial isolates were extracted from $5 \mathrm{ml}$ overnight cultures using Easy DNA Kit with phenol/chloroform (Invitrogen, Cergy Pontoise, France) according to the manufacturer's instructions and suspended in $50 \mu 1$ of TE buffer (Tris-EDTA).

\section{PCR of 16S rRNA gene fragments}

Ribosomal 16S rRNA gene (1450 bp) of all DNA isolates were amplified using the universal primers W02 and W18 as previously described by Callon et al. [9]. All amplifications were performed with a geneAmp PCR System 9700 (Applied Biosystems, Courtaboeuf, France).

\section{Screening by RFLP analysis}

All the 16S PCR products were analyzed by the Restriction Fragment Length Polymorphism (RFLP) method, using the following protocol: in a final volume of $15 \mu \mathrm{l}, 5 \mu \mathrm{l}$ of $16 \mathrm{~S}$ PCR products were added to $0.5 \mu \mathrm{l}$ of EcoR1 and Hae III (MP Biochemical, Vannes, France), $1.5 \mu \mathrm{l}$ of buffer $(100 \mathrm{mM} \mathrm{KCl}, 10 \mathrm{mM}$ tris$\mathrm{HCl}, \quad 0.1 \mathrm{mM}$ EDTA, $10 \mathrm{mM}$ 2-mercaptoethanol, $500 \mu \mathrm{g} / \mathrm{ml} \mathrm{BSA}, 50 \%$ glycerol) and $7.5 \mu \mathrm{l}$ of water. The thermal cycler apparatus was programmed for $1 \mathrm{~h}$ at $37^{\circ} \mathrm{C}$. The amplification products were electrophoresed in $2 \%$ standard agarose gel with TBE $0.5 \times$ and ethidium bromide $(10 \mathrm{mg} / \mathrm{ml})$ for $2 \mathrm{~h}$ at $120 \mathrm{~V}$, using a $50 \mathrm{bp}$ DNA step ladder as standard. The profiles generated were analyzed with BioNumerics software using UPGMA (Unweighted Pair Group Method with arithmetic Average) analysis and a dendogram was deduced from the matrix of similarities. The 16S RFLP profiles of isolates were compared to a reference bank of 16S RFLP profiles realized in a first step by the analysis of 60 different species of the laboratory collection. Isolates showing an identical RFLP pattern at $90 \%$ of similarity were grouped together and one or several $16 \mathrm{~S}$ rDNA from each group were analyzed by sequencing.

\section{Species PCR amplifications}

DNA of Gram-positive and catalase negative isolates were amplified with species-specific primers for Enterococcus faecalis: ddlE1-ddlE2 [13], Lactococcus lactis lactis/cremoris: LhisF5-Lhis6R [5], Leuconostoc mesenteroides: Lnm1-Lnm2 [10], Lactobacillus casei/paracasei: paracasei $16 \mathrm{~S}-16$ reverse [6] and Lactococcus garvieae: Lg1-Lg2 [49].

\section{Partial 16S rRNA gene sequencing}

A $50 \mu 1$ of bacterial $16 \mathrm{~S}$ rRNA gene was purified on column and sequenced using the W34 primer [50] by GeneCust (Evry, France). The $450 \mathrm{bp}$ of the $5^{\prime}$ ends obtained for the seventy-eight 16S rRNA genes of the isolates were compared to sequences available in the GeneBank database, using the BLAST program [2]. Sequences with a percentage similarity of $97 \%$ or higher were considered to represent the same species.

\section{Yeast identification}

Yeast isolates were identified by phenotypic tests $[4,20]$ and the D1/D2 domain of 26S rRNA encoding gene (Primers NL1-NL4) sequencing, as described by Callon et al. [8].

\section{DNA extraction and purification from milk}

The milks were thawed at $25^{\circ} \mathrm{C}$. The DNA extraction method was derived from that of Duthoit et al. [14] for DNA extraction from cheese, with the following modifications: $10 \mathrm{ml}$ of milk were incubated at $37^{\circ} \mathrm{C}$ for $2 \mathrm{~h} 30$ with $150 \mu \mathrm{l}$ of $10 \mathrm{mg} / \mathrm{ml}$ pronase E (Merck, Darmstadt, Germany). One $\mathrm{ml}$ of $20 \%$ sodium dodecyl sulfate was added, and the incubation was continued for $1 \mathrm{~h}$. After centrifugation at $8500 \mathrm{~g}$ for $20 \mathrm{~min}$ at $4{ }^{\circ} \mathrm{C}$, the fat layer was removed and the sample was incubated $10 \mathrm{~min}$ at $30^{\circ} \mathrm{C}$. Then the samples were centrifuged at $8500 \mathrm{~g}$ for $10 \mathrm{~min}$ at room temperature and the microbial 
pellet was resuspended in $130 \mu \mathrm{l}$ of $4 \mathrm{M}$ guanidine thiocyanate- $0.1 \mathrm{M}$ Tris ( $\mathrm{pH} 7.5), 20 \mu \mathrm{l}$ of $10 \%$ $N$-lauroylsarcosine. The phenol/chloroform extraction and DNA precipitation were performed as described by Duthoit et al. [14].

\section{S rRNA gene cloning}

Genomic DNA extracted from six milks spread over the lactation year (milks 90, 95, 103, 116, 151 and 188) was used as template. Amplification and cloning of $16 \mathrm{~S}$ rRNA genes were carried out as described by Duthoit et al. [14] using w02 and w18 primers, except that Pfu DNA polymerase and $10 \times \mathrm{Pfu}$ buffer (Stratagene, St. Quentin en Yvelines, France) were used. PCR products were ligated into pCR4Blunt-TOPO and transformed into Escherichia coli TOP10 OneShot as specified by the manufacturer (Invitrogen, Cergy Pontoise, France). Plasmid inserts were amplified with universal plasmid primers T3 and T7 [14] as specified by the manufacturer. Three hundred and forty-one clones were obtained. A second 16S rDNA PCR was applied with WO2-W18 like for isolates. The 16S PCR products corresponding to the clone inserts were screened by RFLP as described above for isolates and compared to a reference bank of 16S RFLP profiles. Several 16S rDNA from each RFLP cluster were sent to GeneCust for sequencing under the same conditions as described for the isolates. Seventy-nine clones were sequenced.

\section{SSCP-PCR amplification}

Total DNA from 118 milks was used as a template to amplify the V3 region of the bacterial 16S rRNA gene, using the primers w34 and w49 as described by Duthoit et al. [14], except that Pfu DNA polymerase and $10 \times$ Pfu buffer were used. PCR was performed on genomic DNA extracted from the milk, on PCR product from plasmid insert amplification, and on DNA extracted from pure culture. W34 was labeled with $5^{\prime}$-fluorescein phosphoramidite (NED). The primers were synthesized by Applied Biosystems.

Total DNA from 49 milks (1 or 2 per week) were analyzed by yeast SSCP analysis. The V4 region of the 18S rRNA gene was amplified with Lev1 and Lev2 primers as described by Callon et al. [8].

\section{SSCP electrophoresis}

Samples were denatured at $95^{\circ} \mathrm{C}$ for $3 \mathrm{~min}$ and SSCP capillary electrophoresis in non-denaturing condition was performed on an ABI Prism 310 Genetic Analyzer (Applied Biosystems), as previously described [14]. The migration of the DNA fragments depends on their conformation which one depends on their sequence. All SSCP profiles of milks were ligned up using an internal DNA molecular weight standard Genescan-300HD ROX (Applied Biosystems) and an external standard (a same milk analyzed in each run with the others milks). The areas of the peaks were calculated. To analyze the different profiles, we calculated the relative area of the peak $i$ to the sum of the peak areas, $P_{i}=a_{i} / \sum a_{i}$, where $a_{i}$ is the area of one peak.

\section{SSCP peaks assignments}

The peaks in the V3 16S rDNA profiles of the milks were assigned to different species according to their coelution with the clones in the library or strains isolated from goat milks and identified by $16 \mathrm{~S}$ rDNA sequencing. The V3 regions of the 16S rRNA genes in the clone library and in the isolates were analyzed by SSCP.

In the same way, the peaks in the yeast SSCP profiles of the milks were assigned according to coelution with isolates from milks and reference strains representing the yeast communities of a variety of cheeses.

\section{Data analysis}

Discriminant analysis (DA) was performed with Statistica software (Statsoft, version 6) with the four periods as classification variables, the relative areas of the 16S V3 SSCP and 18S V4 SSCP peaks as variables, and the milks as observations.

The counts on media and the relative areas of the bacterial and yeast SSCP peaks form a global profile for each milk. Therefore a Multivariate Analysis of Variance (MANOVA) was performed on these data with the four multivariate test statistics of Statistica software output (Wilks' lambda, Pillai's trace, Hotelling-Lawley and Roy's maximum root). This first analysis were followed by an Analysis of Variance (ANOVA) on data from counts on each media or relative peaks of global SSCP profiles, in order to describe those that are the best discriminated by the period. Tukey's test was performed to compare the means and significant differences were noted $(P<0.05)$.

\section{Results}

\section{Bacterial diversity in goat milk according to clone and isolate identification}

The results of the identification of 281 isolates and 341 clones, after screening by RFLP analysis (results not shown) and 16S rRNA gene sequencing of representative groups are detailed in Tables 1 and 2 . As is it only based on $16 \mathrm{~S}$ rRNA sequence comparison, the 
Table 1. Phylogenetic affiliations of 281 isolates from two different milks (151 and 49): screening of 16S rRNA gene by RFLP analysis followed by $16 \mathrm{~S}$ rRNA gene sequencing

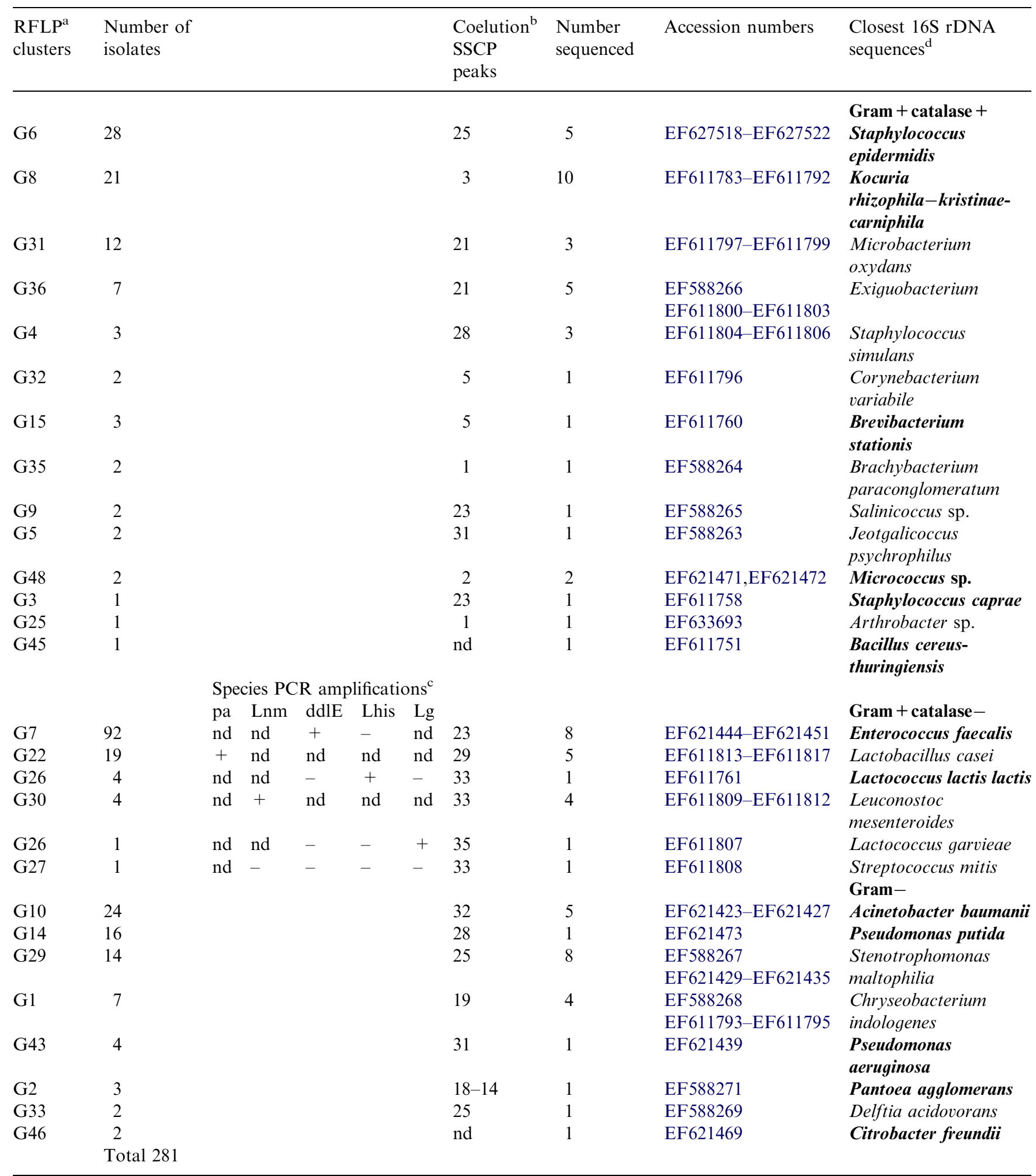

${ }^{\mathrm{a}}$ The RFLP patterns were analyzed with BioNumerics software using UPGMA analysis. Isolates with the same pattern were grouped together and one or several from each group were analyzed by 16S rDNA sequencing.

${ }^{\mathrm{b}}$ The bacterial V3 region of the 16S rDNA gene was analyzed by SSCP and peaks were compared to the V3 16S rDNA SSCP profiles of milks.

cThe description of different primers is given in section "Materials and methods". nd: not determined.

${ }^{\mathrm{d}}$ Species indicated in bold are common to isolates and clones libraries. 
Table 2. Phylogenetic affiliations of OTUs from milks (16S rDNA clone libraries from six different milks: screening of 16S rRNA genes by RFLP followed by 16S rRNA gene sequencing)

\begin{tabular}{|c|c|c|c|c|c|}
\hline $\begin{array}{l}\text { RFLP } \\
\text { clusters }^{\mathrm{a}}\end{array}$ & $\begin{array}{l}\text { Number } \\
\text { of clones }\end{array}$ & $\begin{array}{l}\text { Coelution }^{\mathrm{b}} \\
\text { SSCP } \\
\text { peaks }\end{array}$ & $\begin{array}{l}\text { Number } \\
\text { sequenced }\end{array}$ & Accession numbers & Phylogenetic affiliation after sequencing ${ }^{\mathrm{c}}$ \\
\hline
\end{tabular}

\begin{tabular}{|c|c|c|c|c|c|}
\hline G45 & 8 & 24 & 4 & EF611752-EF611755 & $\begin{array}{l}\text { Gram }+ \text { cat }+ \\
\text { Bacillus cereus-thuringiensis }\end{array}$ \\
\hline G6 & 6 & 25 & 3 & EF621464-EF621466 & Staphylococcus epidermidis \\
\hline G3 & 4 & 23 & 1 & EF611757 & Staphylococcus caprae \\
\hline G8 & 3 & 3 & 3 & EF611780-EF611782 & Kocuria rhizophila-kristinae-carniphila \\
\hline G9 & 1 & 25 & 1 & EF621462 & Staphylococcus equorum \\
\hline G42 & 1 & 1 & 1 & EF621461 & Unidentified \\
\hline G16 & 1 & 24 & 1 & EF611756 & Macrococcus caseolyticus \\
\hline G15 & 1 & 5 & 1 & EF611759 & Brevibacterium stationis \\
\hline G40 & 1 & 3 & 1 & EF588270 & Ornithinicoccus sp. \\
\hline G19 & 1 & 4 & 1 & EF588274 & Dietza maris \\
\hline G48 & 1 & 2 & 1 & EF621470 & Micrococcus sp. \\
\hline G12 & 1 & 3 & 1 & EF621467 & Rothia sp. \\
\hline G13 & 1 & $\mathrm{Nd}$ & 1 & EF621463 & Clostridium \\
\hline G51 & 1 & $\mathrm{Nd}$ & 1 & EF621443 & $\begin{array}{l}\text { Firmicutes sp. } \\
\text { Gram + cat- }\end{array}$ \\
\hline G7 & 54 & 23 & 9 & EF621452-EF621460 & Enterococcus faecalis \\
\hline G26 & 48 & 33 & 18 & EF611762-EF611779 & Lactococcus lactis lactis \\
\hline G49 & 1 & 35 & 1 & EF627486 & $\begin{array}{l}\text { Enterococcus saccharominimus } \\
\text { Gram- }\end{array}$ \\
\hline G2 & 134 & $18-14$ & 10 & EF611741-EF611750 & Pantoea agglomerans \\
\hline G14 & 51 & 28 & 8 & EF627478-EF627485 & Pseudomonas putida \\
\hline G10 & 7 & 32 & 2 & EF6588272-EF621428 & Acinetobacter baumanii \\
\hline G44 & 1 & 25 & 1 & EF588273 & Hahella chejuinsis \\
\hline G43 & 5 & 31 & 3 & EF621436-EF621438 & Pseudomonas aeruginosa \\
\hline G19 & 3 & 20 & 2 & EF613318,EF613319 & Klebsiella milletis- oxytoca \\
\hline G46 & 2 & $\mathrm{Nd}$ & 1 & EF621468 & Citrobacter freundii \\
\hline $\mathrm{G}$ & 2 & $\mathrm{Nd}$ & 2 & EF621440,EF621441 & Pseudomonas fulgida \\
\hline G50 & $\begin{array}{c}1 \\
\text { Tota }\end{array}$ & 23 & 1 & EF621442 & Enterobacter absuriae \\
\hline
\end{tabular}

\footnotetext{
${ }^{a}$ The RFLP patterns were analyzed with BioNumerics software using UPGMA analysis. Isolates with the same pattern were grouped together and one or several from each group were selected and analyzed by $16 \mathrm{~S}$ rDNA sequencing.

${ }^{\mathrm{b}}$ The bacterial V3 region of the 16S rDNA gene was analyzed by SSCP and peaks were compared to V3 16S rDNA SSCP profiles of milks.

${ }^{\mathrm{c}}$ Species indicated in bold are common to isolates and clones libraries.
}

identifications are not strict in a taxonomic sense. Based on the closest affilation of clones and isolates, the presence of 41 different species were suggested from 6 goat milks from the same herd at different periods of the year. Among the Gram-positive, non lactic acid bacteria, sequences affiliated to Staphylococcus epidermidis $(10 \%$ of isolates and $2 \%$ of OTUs) and Kocuria rhizophilakristinae-carniphila ( $8 \%$ of isolates and $1 \%$ of OTUs), Bacillus thuringiensis-cereus, Staphylococcus caprae, Micrococcus sp. and Brevibacterium stationis were found both among the clones and among the isolates. Nine species Microbacterium oxydans and Exiguobacterium (4\% and $2 \%$ of isolates), Staphylococcus simulans (1.5\%), and Corynebacterium variabile, Brachybacterium paraconglomeratum, Arthrobacter sp., Salinicoccus sp., Jeotgalicoccus psychrophilus (less than $1 \%$ ) were present only among the isolates. Seven sequences affiliated to Staphylococcus equorum, Macrococcus caseolyticus, Ornithinicoccus sp., Dietza maris, Rothia sp., Clostridium and Firmicutes sp. (less than $1 \%$ ) were suggested only by $16 \mathrm{~S}$ rRNA cloning.

Among the Gram-positive lactic acid bacteria, the isolates were more diverse than the clones. Sequences affiliated to E. faecalis (33\% of isolates and $16 \%$ of OTUs) were the most commonly found in both isolates and clone libraries, whereas sequences affiliated to $L c$. lactis $(1.5 \%$ of isolates and $14 \%$ of OTUs) were the most commonly recovered among the clones. Four species were only found among the isolates. These were affiliated to $L b$. casei $(7 \%)$, Ln. mesenteroides $(1.5 \%)$, Lc. garvieae and Streptococcus mitis (less than 1\%). The sequence affiliated to Enterococcus saccharominimus (less than $1 \%$ ) was only identified among the clones.

Among the Gram-negative bacteria, sequences affiliated to Pantoea agglomerans (1\% of isolates and $40 \%$ 
Table 3. Identification of yeast isolates from six different milks (72, 81, 168, 181, 209 and 280): phenotypic identification and phylogenetic affiliations identified by $26 \mathrm{~S}$ rRNA gene sequencing

\begin{tabular}{|c|c|c|c|c|c|}
\hline $\begin{array}{l}\text { Number of } \\
\text { isolates }\end{array}$ & $\begin{array}{l}\text { Phenotypic } \\
\text { identification }^{\text {a }}\end{array}$ & $\begin{array}{l}\text { Number } \\
\text { sequenced }\end{array}$ & $\begin{array}{l}\text { Closest 26S rDNA } \\
\text { sequences }\end{array}$ & Accession numbers & $\begin{array}{l}\text { Coelution } \\
\text { SSCP }^{\mathrm{b}} \\
\text { peaks of } \\
\text { milk }\end{array}$ \\
\hline 10 & $\begin{array}{l}\text { Rhodotorula glutinis/ } \\
\text { graminis }\end{array}$ & 8 & $\begin{array}{l}\text { Rhodotorula glutinis/ } \\
\text { graminis }\end{array}$ & EF627488-EF627495 & $\mathrm{s}$ \\
\hline 7 & Trichosporon beigelii & 4 & Trichosporon sp 9 & EF627506-EF627509 & $r$ \\
\hline 6 & Debaryomyces hansenii & 4 & Debaryomyces hansenii & EF627496-EF627499 & $s$ \\
\hline 5 & $\begin{array}{l}\text { Cryptococcus ater } / C r \text {. } \\
\text { magnus }\end{array}$ & 4 & Cryptococcus magnus & EF627513-EF627516 & $m$ \\
\hline 5 & Cryptococcus curvatus & 3 & Cryptococcus curvatus & EF627500-EF627502 & $m$ \\
\hline 4 & Rhodotorula minuta & 1 & Rhodotorula minuta & EF627517 & $f$ \\
\hline 4 & Candida intermedia & 4 & Candida intermedia & EF627505-EF627510-EF627512 & $b$ \\
\hline 2 & Candida pararugosa & 1 & Candida pararugosa & EF627503 & $t$ \\
\hline 1 & Candida inconspicua & 1 & Candida inconspicua & EF627504 & $c$ \\
\hline 1 & Kluyveromyces lactis & 1 & Kluyveromyces lactis & EF627487 & $k$ \\
\hline Total 46 & & & & & \\
\hline
\end{tabular}

${ }^{\text {a }}$ Phenotypic identification using the morphological, biochemical and physiological characteristics of Kurtzman and Fell [20] as described by Callon et al. [8], and assignment to species with the dichotomous key of Barnett et al. [4].

${ }^{\mathrm{b}}$ The V4 region of the 18S rDNA gene was analyzed by SSCP and peaks were compared to V4 $18 \mathrm{~S}$ rDNA SSCP profiles of milks.

of clones), Pseudomonas putida (6\% of isolates and $15 \%$ of clones), Acinetobacter baumanii ( $9 \%$ of isolates and $3 \%$ of clones), Citrobacter freundii and Pseudomonas aeruginosa (less than $1 \%$ ) were identified among both isolates and clones. The three species assigned to Stenotrophomonas maltophilia (6\%), Chryseobacterium indologenes (3\%) and Delftia acidovorans (less than $1 \%$ ) were only encountered among the isolates. Sequences assigned to Enterobacter absuria and Enterobacter sp, Hahella chejuinsis, Klebsiella milletis-oxytoca and Pseudomonas fulgida (less than $1 \%$ ) were identified among the clones.

\section{Yeast diversity in goat milk by isolate identification}

To characterize yeast populations in different milks, 46 isolates were retrieved from OGA medium from six goat milks and characterized phenotypically and genotypically. The results of both types of identification of yeast isolates are detailed in Table 3. Seven main species were distinguished: Rhodotorula glutinis (22\%), Trichosporon beigelii (15\%), Debaryomyces hansenii (15\%), Cryptococcus magnus (11\%), Cryptococcus curvatus (11\%), Rhodotorula minuta $(9 \%)$ and Candida intermedia (9\%). Other species identified (totaling less than 5\% of isolates) were Kluyveromyces lactis, Candida inconspicua and Candida pararugosa.

\section{Discrimination between periods by cell counting on media}

The microbial characteristics of the milks were evaluated by cell counting on different media. The selectivity of the different media was assessed as shown in Table 4. The microbial community retrieved from CRBM agar plates consisted of Gram-positive catalase positive genera (Staphylococcus, Kocuria, Corynebacterium, Arthrobacter, Salinicoccus, Jeotgalicoccus, Brevibacterium and Brachybacterium), although some Enterococcus were also found. Isolates from PCAI agar medium belonged to the Gram-negative genera Stenotrophomonas, Chryseobacterium, Delftia, Pseudomonas and Pantoea. The bacteria retrieved from M17 agar at $30^{\circ} \mathrm{C}$ were very diverse and belonged to various Grampositive genera such as Kocuria, Microbacterium, Micrococcus, Brachybacterium, Bacillus, Exiguobacterium, Enterococcus, Lactococcus and to Gram-negative genera such as Acinetobacter, Pseudomonas, Stenotrophomonas, Chryseobacterium and Citrobacter. The bacterial community identified on M17 agar at $42{ }^{\circ} \mathrm{C}$ was more selective, as Enterococcus and one strain of Lactococcus predominated and only one isolate of Pantoea was found. The FH medium was selective for mesophilic Lactobacilli, while the SB medium selected for $E$. faecalis. Isolates retrieved from the TA medium belonged to E. faecalis and Lc. lactis and the majority of isolates from the MSE agar medium were identified as E. faecalis, with a few Ln. mesenteroides. The bacterial community identified on the RPF medium was composed essentially of the genera Staphylococcus, Microbacterium, Exiguobacterium, Brevibacterium and sporadically of Enterococcus. The CFC agar medium mainly selected for Pseudomonas.

The counts on the different media were used as dependant variables for MANOVA analysis, with the 
Table 4. Frequency of each species identified on the different cell counting media

Media $\begin{array}{ll}\text { Total } \\ \text { isolates }\end{array} \quad$ Species as percentage of isolates

Cheese ripening bacteria media (CRBM).

Incubation: 5 days at $37^{\circ} \mathrm{C}$

Plate count agar + cristal violet inhibitor (PCAI). Incubation: 3 days at $30{ }^{\circ} \mathrm{C}$

Terzaghi and Sandine M17. Incubation: 2 days at $30^{\circ} \mathrm{C}$

Terzaghi and Sandine M17. Incubation: 2 days at $42^{\circ} \mathrm{C}$

Turner Sandine Elliker with acide nalidixique $(30 \mathrm{mg} / \mathrm{l})$ (TA). Incubation: 2 days at $30^{\circ} \mathrm{C}$

Slanetz and Bartley (SB). Incubation: 2 days at $42{ }^{\circ} \mathrm{C}$

Facultatively heterofermentative lactobacilli (FH). Incubation: 3 days at $30^{\circ} \mathrm{C}$ in anaerobiose Mayeux Sandine Elliker (MSE). Incubation: 2 days at $30^{\circ} \mathrm{C}$

Cetrimin-fucidin-cephalosporin (CFC).

Incubation: 2 days at $25^{\circ} \mathrm{C}$

Rabbit plasma fibrinogen (RPF). Incubation: 2 days at $37^{\circ} \mathrm{C}$
40

Kocuria sp. 30\%; Enterococcus faecalis 30\%; Staphylococcus epidermidis 13\%; Corynebacterium variabile 5\%; Salinicoccus sp. $5 \%$, Jeotgalicoccus psychrophilus 5\%; Brevibacterium stationis $6 \%$; Brachybacterium paraconglomerans 3\%; Arthrobacter $s p$. $3 \%$

18 Stenotrophomonas maltophilia $56 \%$; Chryseobacterium indologenes 17\%; Delftia acidovorans 11\%; Pseudomonas aeruginosa $11 \%$; Pantoea agglomerans 5\% Acinetobacter baumanii 35\%; Kocuria sp. 13\%; Microbacterium oxydans 7\%; E. faecalis 7\%; Ps. aeruginosa 7\%; Ch. indologenes 6\%; Ste. maltophilia 6\%; Micrococcus sp. 3\%; Citrobacter freundii $3 \%$; Pseudomonas putida $3 \%$; Br. paraconglomerans $2 \%$; Exiguobacterium 2\%; Bacillus cereus 2\%; Lactococcus garvieae $2 \%$

10 E. faecalis $80 \%$; Streptococcus mitis $10 \%$; P. agglomerans $10 \%$

8 E. faecalis $50 \%$; Lactococcus lactis $50 \%$

11 E. faecalis $100 \%$

19 Lactobacillus casei $100 \%$

54 E. faecalis $95 \%$; Leuconostoc mesenteroides $5 \%$

12 Ps. putida $92 \%$; Ln. mesenteroides $8 \%$

42

S. epidermidis $53 \%$; Mic. oxydans $16 \%$; Exiguobacterium $14 \%$; Staphylococcus simulans $8 \%$ Staphylococcus caprae 3\%; Br. stationis 3\%; E. faecalis 3\%

Table 5. Microbial counts $(\log 10 \mathrm{cfu} / \mathrm{ml})$ of milks on different media

\begin{tabular}{|c|c|c|c|c|c|c|c|c|c|}
\hline \multirow[t]{2}{*}{ Counts on media } & \multirow[t]{2}{*}{ Significance } & \multicolumn{2}{|c|}{ Period 1 (16 milks) } & \multicolumn{2}{|c|}{ Period 2 (33 milks) } & \multicolumn{2}{|c|}{ Period 3 (44 milks) } & \multicolumn{2}{|c|}{ Period 4 (23 milks) } \\
\hline & & Mean $^{1}$ & $\mathrm{SD}$ & Mean & $\mathrm{SD}$ & Mean & $\mathrm{SD}$ & Mean & $\mathrm{SD}$ \\
\hline $\mathrm{FH}$ & $* * *$ & $1.73 \mathrm{~b}$ & 0.43 & $1.31 \mathrm{a}$ & 0.43 & $2.40 \mathrm{c}$ & 0.74 & $2.26 \mathrm{c}$ & 0.56 \\
\hline $\mathrm{CFC}$ & $* * *$ & $2.71 \mathrm{c}$ & 1.35 & $2.30 \mathrm{bc}$ & 0.93 & $1.77 \mathrm{~b}$ & 1.41 & $0.86 \mathrm{a}$ & 1.10 \\
\hline RPF & $* * *$ & $2.76 \mathrm{a}$ & 0.51 & $2.92 \mathrm{ab}$ & 0.22 & $3.03 \mathrm{bc}$ & 0.23 & $3.15 \mathrm{c}$ & 0.27 \\
\hline PCAI & $* * *$ & $2.83 \mathrm{ab}$ & 0.77 & $2.74 \mathrm{a}$ & 0.60 & $3.30 \mathrm{bc}$ & 0.70 & $3.40 \mathrm{bc}$ & 0.60 \\
\hline VRBG & $* * *$ & $0.84 \mathrm{a}$ & 0.94 & $1.11 \mathrm{a}$ & 0.90 & $2.01 \mathrm{~b}$ & 1.13 & $1.80 \mathrm{~b}$ & 1.03 \\
\hline MSE & $* * *$ & $3.67 \mathrm{~b}$ & 0.38 & $2.98 \mathrm{a}$ & 0.86 & $3.26 \mathrm{ab}$ & 0.64 & $3.21 \mathrm{a}$ & 0.33 \\
\hline CRBM & $* *$ & $3.67 \mathrm{~b}$ & 0.20 & $3.28 \mathrm{a}$ & 0.45 & $3.51 \mathrm{ab}$ & 0.50 & $3.35 \mathrm{a}$ & 0.31 \\
\hline OGA & $* *$ & $1.37 \mathrm{a}$ & 0.99 & $1.40 \mathrm{a}$ & 0.88 & $1.92 \mathrm{ab}$ & 0.86 & $2.00 \mathrm{~b}$ & 0.69 \\
\hline TA & $*$ & $4.22 \mathrm{~b}$ & 0.75 & $3.93 \mathrm{ab}$ & 1.15 & $3.76 \mathrm{ab}$ & 1.07 & $3.35 \mathrm{a}$ & 1.23 \\
\hline
\end{tabular}

${ }^{1}$ Mean values of counts of all milks from the period.

$\mathrm{a}, \mathrm{b}, \mathrm{c}$ : Letters indicate homogeneous statistical processing groups within row that were significantly different according to the Tukey statistical test $(P<0.05)$, with $\mathrm{a}<\mathrm{b}<\mathrm{c}$.

$* * * P<0.001 ; * * P<0.01 ; * P<0.05$.

Abbreviations of media are given in Table 4.

period as categorial predictor. The four multivariate test statistics of Statistica output (Wilks' lambda, Pillai's trace, Hotelling-Lawley and Roy's maximum root) showed a significant effect of the period on global profiles of milks, with a $P$-value $<0.001$. Univariate tests have been realized to describe the populations that are the best implied in this effect. The mean values (expressed as $\log _{10} \mathrm{cfu} / \mathrm{ml}$ ) and standard deviation of 
each medium for the four periods are indicated in Table 5. The counts on $\mathrm{M} 17$ at $30^{\circ} \mathrm{C}, \mathrm{M} 17$ at $42{ }^{\circ} \mathrm{C}$ and SB media did not differ significantly according to the periods. The variables that best discriminated between periods were the counts on the FH, CFC, RPF, PCAI, VRBG and MSE $(P<0.001)$ media, followed by counts on the CRBM, OGA and TA $(P<0.05)$ media.

Taking into account the media's selectivity, the counts of Enterococcus were stable throughout the lactation year. The counts of mesophilic Lactobacillus, Gramnegative bacteria, Staphylococcus and coryneform bacteria increased during the year and reached their highest counts in milks from P3 and P4. The counts of the Pseudomonas and Lactococcus were highest in milks from P1, decreasing steadily to reach their lowest levels in milks from $\mathrm{P} 4$.

\section{Discrimination between periods by $16 \mathrm{~S}$ rDNA SSCP analysis}

The SSCP patterns of the bacterial 16S rDNA V3 region varied quite widely between different milks, as illustrated in Fig. 1.

A one-way discriminant analysis was first performed (results not shown) to check the classification of the milks in the four defined periods according to the relative peak areas of the V3 $16 \mathrm{~S}$ rDNA profiles. The results showed that some milks were not classified in the period defined as described in Material and methods section. This concerned two milks from $\mathrm{P} 1$, four from $\mathrm{P} 2$, five from $\mathrm{P} 3$ and four from $\mathrm{P} 4$ which were not taken into account in the following analysis.

The relative areas of the 39 peaks from the V3 16S rDNA profiles of 103 milks were used as dependent variables in MANOVA, with the period as categorial predictor. It was observed that the period had a significant effect on global profiles of milks with a $P$-value $<0.01$ for the four multivariate test statistics of Statistica output. Univariate tests have been realized to evaluate the significance of this effect on the different populations. Eighteen peaks had a significant effect in differentiating milks from the four periods, as shown in Table 6A. Peaks 19, 32, 13, 7, 20, 9, 35, 3 and 22 were the most discriminating $(P<0.001)$ followed by peaks $36,8,37,39,2,12,21,27$ and 17. The different peaks were assigned to one or several species as shown in Tables 2 and 3. In the V3 16S rDNA profiles of milks from $\mathrm{P} 1$, the highest relative areas were those for the peak corresponding to the sequence of Lc. garvieae, as shown by the evolution of peak 35 . These relative areas slightly decreased in the SSCP milk profiles of P2 and were low in the V3 16S rDNA profiles of milks from P3 and P4. All peaks in the V3 16S rDNA profiles of milks

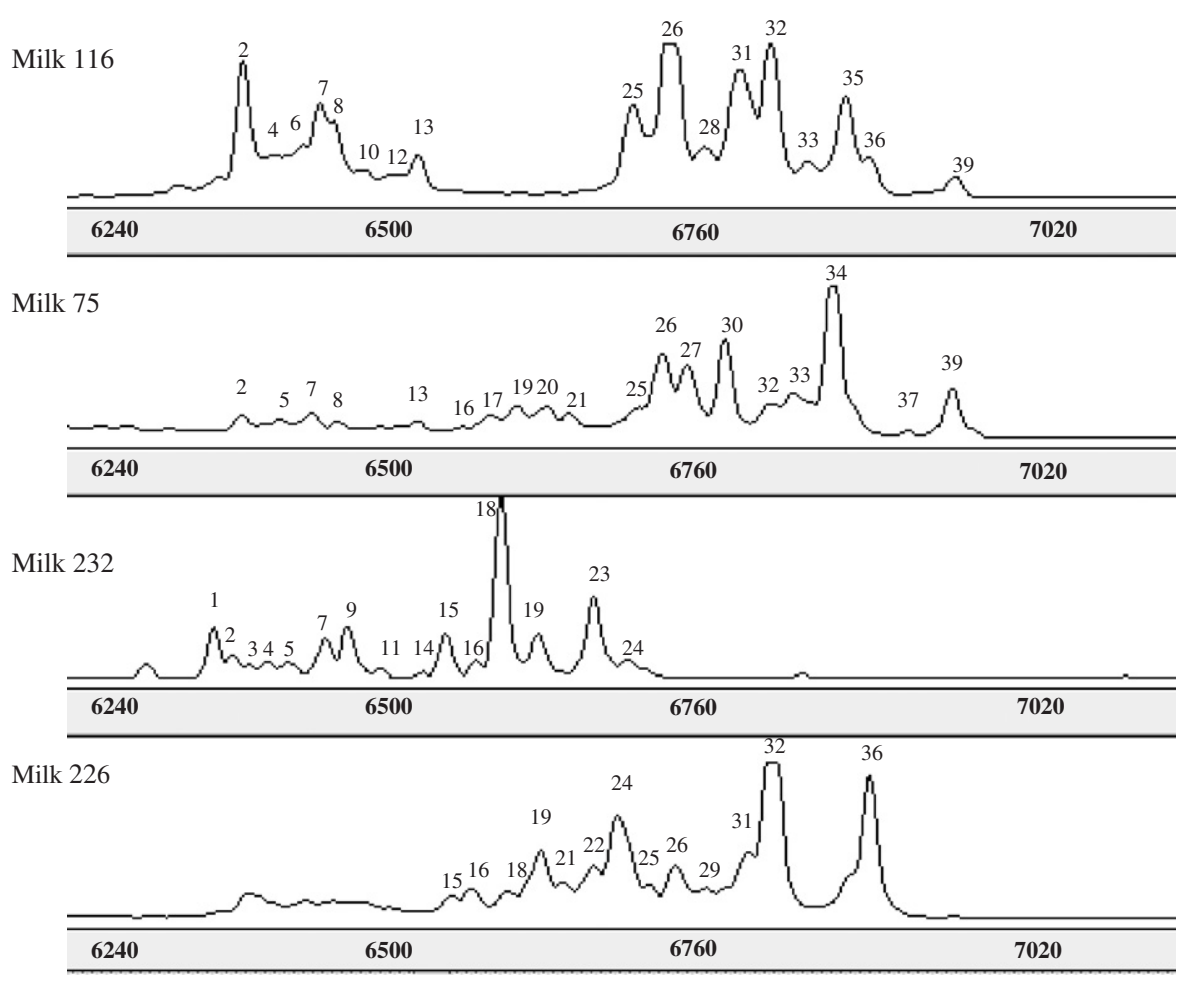

Fig. 1. Diversity of bacterial $16 \mathrm{~S}$ rDNA region V3 SSCP profiles of four different milks: milk 75 (period 1), milk 116 (period 2), milks 226 and 232 (period 3). Thirty-nine different peaks were observed among the $118 \mathrm{~V} 316 \mathrm{~S}$ rDNA profiles of the milks. The profiles of milks have been lined up according to internal and external standards. $Y$-axis: fluorescens. $X$-axis: elution time expressed "in scans" (arbitrary unit of analysis software). The assignment of peaks to species is shown in Tables 2 and 3. 
Table 6. Ratio of 16S V3 SSCP (A) and 18S V4 SSCP (B) peaks having a significant effect in differentiating the milks from the four periods by univariate tests

\begin{tabular}{|c|c|c|c|c|c|c|c|c|c|}
\hline \multicolumn{10}{|l|}{ (A) $16 \mathrm{~S} \mathrm{~V} 3 \mathrm{SSCP}$} \\
\hline \multirow[t]{2}{*}{ V3 SSCP peaks ${ }^{1}$} & \multirow[t]{2}{*}{ Significance } & \multicolumn{2}{|c|}{ Period 1 (14 milks) } & \multicolumn{2}{|c|}{ Period 2 (29 milks) } & \multicolumn{2}{|c|}{ Period 3 (39 milks) } & \multicolumn{2}{|c|}{ Period 4 (20 milks) } \\
\hline & & Mean $^{2}$ & $\mathrm{SD}$ & Mean & $\mathrm{SD}$ & Mean & $\mathrm{SD}$ & Mean & $\mathrm{SD}$ \\
\hline 2 & $* *$ & $1.40 \mathrm{a}$ & 1.52 & $3.81 \mathrm{~b}$ & 3.38 & $3.39 \mathrm{ab}$ & 2.92 & $1.81 \mathrm{ab}$ & 1.57 \\
\hline 3 & $* * *$ & $1.5 \mathrm{~b}$ & 1.9 & $0.005 \mathrm{a}$ & 0.02 & $0.31 \mathrm{a}$ & 0.82 & $0.35 \mathrm{a}$ & 1.08 \\
\hline 7 & $* * *$ & $1.05 \mathrm{ab}$ & 0.79 & $209 \mathrm{~b}$ & 2.28 & $0.46 \mathrm{a}$ & 1.24 & $0.29 \mathrm{a}$ & 0.44 \\
\hline 8 & $* *$ & $0.37 \mathrm{a}$ & 0.58 & $1.62 \mathrm{~b}$ & 2.09 & $0.89 \mathrm{ab}$ & 1.00 & $0.16 \mathrm{a}$ & 0.50 \\
\hline 9 & $* * *$ & $0.22 \mathrm{a}$ & 0.44 & $0.37 \mathrm{a}$ & 0.85 & $1.77 \mathrm{~b}$ & 2.45 & $2.50 \mathrm{~b}$ & 1.80 \\
\hline 12 & $* *$ & $0.32 \mathrm{a}$ & 0.50 & $1.21 \mathrm{~b}$ & 1.39 & $0.59 \mathrm{ab}$ & 0.65 & $0.59 \mathrm{ab}$ & 0.65 \\
\hline 13 & $* * *$ & $0.36 \mathrm{ab}$ & 0.62 & $1.25 \mathrm{~b}$ & 2.19 & $0.04 \mathrm{a}$ & 0.17 & $0.00 \mathrm{a}$ & 0.00 \\
\hline 17 & $*$ & $0.29 \mathrm{a}$ & 0.76 & $1.19 \mathrm{ab}$ & 1.55 & $3.36 \mathrm{~b}$ & 6.02 & $1.27 \mathrm{ab}$ & 4.19 \\
\hline 19 & $* * *$ & $0.55 \mathrm{a}$ & 1.03 & $1.50 \mathrm{a}$ & 2.85 & $1.37 \mathrm{a}$ & 2.63 & $11.73 \mathrm{~b}$ & 4.65 \\
\hline 20 & $* * *$ & $0.48 \mathrm{a}$ & 0.79 & $0.77 \mathrm{a}$ & 1.04 & $5.68 \mathrm{~b}$ & 5.91 & $0.30 \mathrm{a}$ & 1.12 \\
\hline 21 & $*$ & $0.61 \mathrm{a}$ & 0.97 & $0.63 \mathrm{a}$ & 1.54 & $1.75 \mathrm{ab}$ & 3.09 & $2.44 \mathrm{~b}$ & 1.43 \\
\hline 22 & $* * *$ & $1.90 \mathrm{a}$ & 2.66 & $2.21 \mathrm{~b}$ & 3.34 & $4.49 \mathrm{c}$ & 2.48 & $4.38 \mathrm{bc}$ & 2.27 \\
\hline 27 & $*$ & $2.32 \mathrm{~b}$ & 3.93 & $0.17 \mathrm{a}$ & 0.69 & $1.87 \mathrm{ab}$ & 3.66 & $1.20 \mathrm{ab}$ & 1.24 \\
\hline 32 & $* * *$ & $10.42 \mathrm{a}$ & 10.22 & $9.66 \mathrm{a}$ & 9.65 & $14.58 \mathrm{a}$ & 8.03 & $27.70 \mathrm{~b}$ & 9.17 \\
\hline 35 & $* * *$ & 13.09 bc & 11.12 & $14.28 \mathrm{c}$ & 12.68 & $3.65 \mathrm{a}$ & 5.61 & $6.09 \mathrm{ab}$ & 7.52 \\
\hline 36 & $* *$ & $8.26 \mathrm{~b}$ & 7.48 & $2.92 \mathrm{a}$ & 5.20 & $8.01 \mathrm{~b}$ & 5.95 & $8.83 \mathrm{~b}$ & 3.52 \\
\hline 37 & $* *$ & $0.37 \mathrm{a}$ & 0.49 & $2.04 \mathrm{~b}$ & 3.33 & $0.35 \mathrm{a}$ & 0.69 & $0.39 \mathrm{a}$ & 0.97 \\
\hline & $* *$ & $1.46 \mathrm{a}$ & 2.40 & $5.47 \mathrm{~b}$ & 6.72 & $1.44 \mathrm{a}$ & 3.28 & $0.98 \mathrm{a}$ & 1.94 \\
\hline \multicolumn{10}{|l|}{ (B) $18 \mathrm{~S} \mathrm{~V} 4 \mathrm{SSCP}$} \\
\hline \multirow[t]{2}{*}{ V4 SSCP peaks ${ }^{1}$} & Significance & \multicolumn{2}{|c|}{ Period 1 (8 milks) } & \multicolumn{2}{|c|}{ Period 2 (8 milks) } & \multicolumn{2}{|c|}{ Period 3 (20 milks) } & \multicolumn{2}{|c|}{ Period 4 (13 milks) } \\
\hline & & Mean $^{2}$ & SD & Mean & SD & Mean & SD & Mean & $\mathrm{SD}$ \\
\hline $\mathrm{c}$ & $* * *$ & $4.01 \mathrm{a}$ & 4.72 & $0.37 \mathrm{a}$ & 0.98 & $3.08 \mathrm{a}$ & 0.8 & $27.3 \mathrm{~b}$ & 13.28 \\
\hline$f$ & $* * *$ & $0.00 \mathrm{a}$ & 0.7 & $0 \mathrm{a}$ & 0 & $0 \mathrm{a}$ & 0 & $4.01 \mathrm{~b}$ & 2.56 \\
\hline d & $* * *$ & $1.36 \mathrm{a}$ & 2.73 & $0 \mathrm{a}$ & 0 & $1.87 \mathrm{a}$ & 2.5 & $17.4 \mathrm{~b}$ & 10.14 \\
\hline $\mathrm{k}$ & $*$ & $2.88 \mathrm{ab}$ & 3.96 & $4.29 \mathrm{ab}$ & 6.64 & $11.1 \mathrm{c}$ & 10.41 & $1.71 \mathrm{a}$ & 3.82 \\
\hline $\mathrm{m}$ & $*$ & $36.1 \mathrm{ab}$ & 17.17 & $44.68 \mathrm{c}$ & 38.28 & $18.7 \mathrm{ab}$ & 16.16 & $16.17 \mathrm{a}$ & 16.19 \\
\hline $\mathrm{s}$ & $*$ & 23.65 b & 16.43 & $2.44 \mathrm{a}$ & 5.99 & $7.99 \mathrm{a}$ & 7.66 & $3.7 \mathrm{a}$ & 7.84 \\
\hline
\end{tabular}

${ }^{1}$ All the peaks are named in Figs. 1 and 2.

${ }^{2}$ Mean values of $16 \mathrm{~S} \mathrm{V3} \mathrm{(A)} \mathrm{or} \mathrm{18S} \mathrm{V4} \mathrm{SSCP} \mathrm{(B)} \mathrm{peak} \mathrm{ratio} \mathrm{of} \mathrm{all} \mathrm{milks} \mathrm{from} \mathrm{the} \mathrm{period.}$

$\mathrm{a}, \mathrm{b}, \mathrm{c}$ : Letters indicate homogeneous statistical processing groups within row that were significantly different according to the Tukey statistical test $(P<0.05)$, with $\mathrm{a}<\mathrm{b}<\mathrm{c}$.

$* * * P<0.001 ; * * P<0.01 ; * P<0.05$ 
from P2 had globally low relative areas, with no peak predominating. However, peak 2 (corresponding to the Micrococcus sp. sequence) and peak 39 had the highest relative areas and peak 36 (unidentified) the lowest. In the V3 16S rDNA profiles of milks from P3, peak 20 (corresponding to the Klebsiella sequence) and peak 18 (assigned to $P$. agglomerans) had the highest relative areas. In the V3 $16 \mathrm{~S}$ rDNA profiles of the milks from P4, peak 19 (assigned to Ch. indologenes), peak 32 (corresponding to the $A c$. baumanii sequence) and peaks 9 (C. casei) and 21 (Microbacterium, Exiguobacterium) had the highest relative areas.

\section{Discrimination between periods by 18 SDNA SSCP analysis}

Forty-nine milks were characterized by determining their 18S rDNA region V4 SSCP profiles. Examples of the V4 18S rDNA profiles of different milks are shown in Fig. 2. Considering the profiles from all the milks, 26 different peaks were identified. As with the 16S rDNA analysis, a one-way discriminant analysis was performed to check the classification of the milks in the four

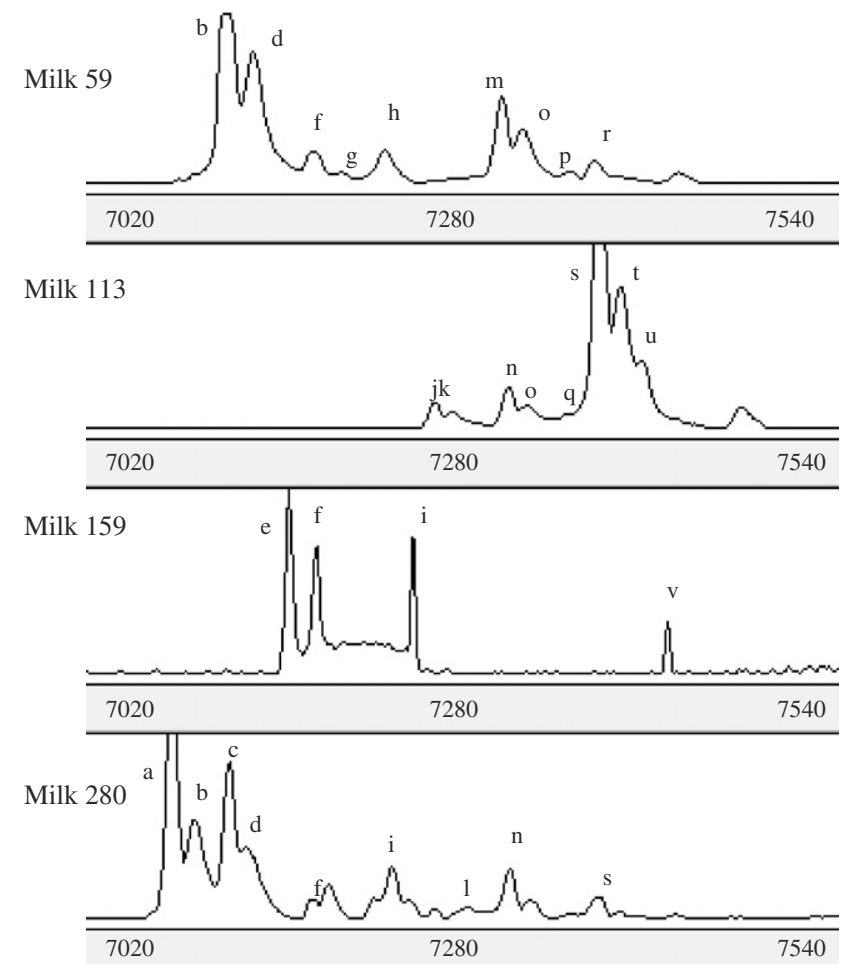

Fig. 2. Diversity of $18 \mathrm{~S}$ rDNA region V4 SSCP profiles of four different milks: milk 59 (period 1), milks 113 and 159 (period 2), 280 (period 4). Twenty-six different peaks were observed among the 49 V4 $18 \mathrm{~S}$ rDNA profiles of the milks. The profiles of milks have been lined up according to internal and external standards. $Y$-axis: fluorescens. $X$-axis: elution time expressed "in scans" (arbitrary unit of analysis software). The assignment of peaks to species is shown in Table 4 . periods according to the relative areas of the different peaks in the profiles. The results revealed some milks were not classified in defined periods (results not shown). This concerned four milks from P1, two from $\mathrm{P} 2$, one from $\mathrm{P} 3$ and one from $\mathrm{P} 4$ which were not taken into account in the following analysis.

The relative areas of the peaks from the V4 18S rDNA profiles of 41 milks were used as dependent variables in a MANOVA to determine the effect of the period factor. It was observed that the period had a significant effect on global profiles of milks with a $P$-value $<0.01$ for the four multivariate test statistics of Statistica output. Univariate tests were performed to describe the effect of period on specific peaks; there was a significant effect on six peaks. The results are detailed in Table 6B. Peaks were identified by coelution with milk isolates, as shown in Table 3. Regardless of these results, the peak $s$, corresponding to the Rh. glutinis and D. hanseni sequences, had the highest relative areas in the V4 18S rDNA profiles of milks from $\mathrm{P} 1$. The relative areas of this peak barely decreased in the V4 18S rDNA profiles of milks from $\mathrm{P} 2$ and then increased gently in those from $\mathrm{P} 3$. In the V4 18S rDNA profiles of milks from $\mathrm{P} 2$ two peaks, $f$ (assigned to Rh. minuta) and $d$ (unidentified) were absent and peaks $c$ (assigned to $C$. inconspicua) and $s$ had the lowest relative areas. Peak $m$ (assigned to $C r$. magnus or Cr. curvatus) had the highest relative areas. In the V4 18S rDNA profiles of milks from P3 no peak corresponding to $R h$. minuta appeared and peak $k$ corresponding to Kl. lactis had the highest relative areas. In the V4 18S rDNA profiles of the milks from P4, peaks $c$ (C. inconspicua), $f(R h$. minuta $)$ and $d$ had the highest relative areas.

\section{Discussion}

This study gives the first overall analysis of microbial communities in raw goat milks.

The analysis was conducted on milk taken from the same herd at different periods. The combination of direct and culture-dependent methods enabled us to identify 42 different species of bacteria, reflecting the bacterial complexity of raw goat milk.

The diversity of the lactic acid bacteria was not very great. The species E. faecalis, Lc. lactis, Lb. casei and $L n$. mesenteroides, extensively described in the literature, were also detected, with a predominance of $E$. faecalis as has often been reported in goat milks $[15,42,48]$. The presence of $L c$. garvieae in goat milk was mentioned by Morea et al. [31]. 16S rRNA sequence comparison suggests presence of St. mitis and E. saccharominimus based on sequence similarities of $98 \%$. These have never been described in goat milk.

Our study shows a wider diversity of Gram-positive non-lactic acid bacteria than is described in the 
literature. Our results confirm the presence of different species of Staphylococcus (S. epidermidis, S. simulans, $S$. caprae and $S$. equorum) and Micrococcus sp. already reported in goat milks [21,34,39]. The species $S$. epidermidis and $S$. caprae and $S$. simulans are classically implicated in goat mammary infections $[16,24,33]$. S. epidermidis is known to be more chronically persistent [33], which explains why it was the most frequently isolated from the milks. Other species such as $K$. rhizophila and K. carniphila, Mic. oxydans, Exiguobacterium, $B$. thuringiensis have been described in raw cow milk, whereas $C$. variabile, $A$. arilaitensis, $B r$. paraconglomerans, Clostridium, Rothia have only been described in cheeses [14]. The numerous corynebacteria we isolated from the milks could come, like Staphylococcaceae, from the skin of the goats' udders, as shown by Contreras et al. [11]. However, preliminary isolate identification based on 16S rRNA sequences also suggests presence of two species, Salinicoccus sp. and $J$. psychrophilus, which have not previously been identified in milk. J. psychrophilus is a halophilic bacterium which has only been isolated from the traditional Korean fermented seafood jeotgal [47]. These species have also been described in association with Arthrobacter and D. maris from incoming process water in the leather industry [35]. The genus Salinicoccus has been isolated from various hypersaline environments [40]. All these halophilic species may have several origins: feed with high $\mathrm{NaCl}$ content, cleaning agent for tank and milking machine. Another atypical genus among dairy bacteria found in this study was Ornithinicoccus sp., which has never been mentioned in milk but is described as a garden soil actinomycete [17]. It is not surprising as soil can contaminate teats and further milk.

Our study also highlights the presence of numerous Gram-negative bacteria. P. agglomerans was the predominant species isolated from raw milk, confirming the results observed by Pisano et al. [36] in raw ewes' milks. The association of Pantoea with the halophilic species Exiguobacterium mentioned above has been observed in marine water pipeline biofilm by Lopez et al. [26]. Pseudomonas was another predominant Gram-negative flora, certainly due to its frequent presence on the skins of goats' udders [11] and possible contamination by water [25]. Pseudomonas may also be selected for by the storage of milk at $4{ }^{\circ} \mathrm{C}$. The presence of Chryseobacterium in dairy products was reported by Jooste et al. [19]. However, the presence of $H$. chejuinsis is atypical for milk; it has only been described in the literature as a halophilic bacteria of marine environments [23].

The diversity of the yeast community was also evaluated, and confirmed the presence of $D$. hansenii, Kl. lactis, Tr. beigelii and Rh. glutinis in goat milks $[38,44]$. The species $C$. pararugosa and $C$. intermedia have been isolated in cow milks [8] whereas $C r$. magnus and $R h$. minuta have only rarely been described in milk or cheese.

Culture-dependent and direct methods were complementary for evaluating the diversity and both showed instability in the microbial composition of the milk over the lactation year. We observed changes in the microbial balance between milks from different periods defined according to breeding conditions. These changes may be linked to several factors. Firstly, the results show a seasonal effect due to the combined effects of feeding regime, physiological state and weather on the milk microbial communities. Secondly, counts of Lactococcus on TA medium and Pseudomonas on CFC medium were the highest in milks during the winter period (period P1) and decreased in spring and summer. This tendency was confirmed by SSCP analysis, in which the peaks corresponding to sequences of $L c$. garvieae and $L c$. lactis showed higher ratios in milk profiles in winter than in the other periods. The summer and autumn milks (periods P3 and P4) on the other hand showed higher counts of Gram-negative bacteria on PCAI and VRBG media, and of Staphylococcus and Corynebacteria on RPF medium, than in other periods. The SSCP analysis confirmed these results. In the milks from P3 the sequences of Klebsiella and $P$. agglomerans had the highest peak ratios, while in the milks from $\mathrm{P} 4$ the sequences of Ch. indologenes, Ac. baumanii, Corynebacterium, Microbacterium and Exiguobacterium had the highest peak ratios. These seasons were also associated with changes in the goats' feeding regime and location. In winter and summer, the goats were fed indoors with dried alfalfa whereas in autumn, they were outdoors and fed on Graminaceae. Volume of milk also varied, being lowest in summer and autumn. However, the microbial community was quite stable within a given period, even if a few milks in each period were classed in the wrong period. This may be due to particular events such as weather conditions, rain particularly. For example, the misclassification of milks from periods 2 or 3 , classed in period 4 because of the high relative areas of the $C h$. indologenes peaks, may be linked to rainy days. The health of the animals may be also involved in abnormal profile changes because mastitis and diarrhea were also observed some days before the milk sample was taken. All these hypothesis should be checked in further experimental studies.

In conclusion, the dual approach applied in this study provides new tools for studying the microbial ecology of raw milk by taking account the sources of contamination and the factors affecting their composition.

\section{Acknowledgments}

This work was supported by ACTA (Association de coordination technique Agricole) - ACTIA (Association 
de coordination pour l'industrie Agroalimentaire) and was conducted in partnership with the Institut de l'Élevage and the Pradel experimental station (Station Expérimentale du Pradel). The authors also very sincerely thank Béatrice Desserre and Robert Didienne for her technical assistance. This work was English proofreading by Harriet Coleman.

\section{References}

[1] C. Alonso-Calleja, J. Carballo, R. Capita, A. Bernardo, M.L. Garcia-Lopez, Changes in the microflora of valdeteja raw goat's milk cheese throughout manufacturing and ripening, Lebensm. Wissenschaft Technol. 35 (2002) 222-232.

[2] S.F. Altschul, W. Gish, W. Miller, E.W. Myers, D.J. Lipman, Basic local alignment search tool, J. Mol. Biol. 215 (1990) 403-410.

[3] F. Ampe, N. ben Omar, C. Moizan, C. Wacher, J.P. Guyot, Polyphasic study of the spatial distribution of microorganisms in Mexican pozol, a fermented maize dough, demonstrates the need for cultivation-independent methods to investigate traditional fermentations, Appl. Environ. Microbiol. 65 (1999) 5464-5473.

[4] J.A. Barnett, R.W. Payne, D. Yarrow, Yeasts: Characteristics and Identification, second ed., Cambridge University Press, Cambridge, England, 1990.

[5] C. Beimfohr, W. Ludwig, K.H. Schleifer, Rapid genotypic differentiation of Lactococcus lactis subspecies and biovar, Syst. Appl. Microbiol. 20 (1997) 216-221.

[6] F. Berthier, E. Beuvier, A. Dasen, R. Grappin, Origin and diversity of mesophilic lactobacilli in Comté cheese, as revealed by PCR with repetitive and species-specific primers, Int. Dairy J. 11 (2001) 293-305.

[7] M. Buffa, B. Guamis, C. Royo, A.J. Trujillo, Microbial changes throughout ripening of goat cheese made from raw, pasteurized and high pressure treated milk, Food Microbiol. 18 (2001) 45-51.

[8] C. Callon, C. Delbès, F. Duthoit, M.C. Montel, Application of SSCP-PCR fingerprinting to profile the yeast community in raw milk Salers cheeses, Syst. Appl. Microbiol. 29 (2006) 172-180.

[9] C. Callon, L. Millet, M.C. Montel, Diversity of lactic acid bacteria isolated from AOC Salers cheese, J. Dairy Res. 71 (2004) 231-244.

[10] R. Cibick, E. Lepage, P. Tailliez, Molecular diversity of Leuconostoc mesenteroides and Leuconostoc citreum isolated from traditional french cheeses as revealed by RAPD fingerprinting, 16S rDNA sequencing and 16S rDNA fragment amplification, Syst. Appl. Microbiol. 23 (2000) 267-278.

[11] A. Contreras, J.C. Corrales, A. Sanchez, D. Sierra, Persistence of subclinical pathogens in goats throughout lactation, J. Dairy Sci. 80 (1997) 2815-2819.

[12] S. Coppola, G. Blaiotta, D. Ercolini, G. Moschetti, Molecular evaluation of microbial diversity occurring in different types of Mozzarella cheese, J. Appl. Microbiol. 90 (2001) 414-420.
[13] S. Dukta-malen, S. Evers, P. Courvalin, Detection of glycopeptide resistance genotypes and identification to the species level of clinically relevant enterococci by PCR, J. Clin. Microbiol. 33 (1995) 24-27.

[14] F. Duthoit, J.J. Godon, M.C. Montel, Bacterial community dynamics during production of "Registered Designation of Origin" Salers cheese as evaluated by $16 \mathrm{~S}$ rRNA gene SSCP analysis, Appl. Environ. Microbiol. 69 (2003) $3840-3848$.

[15] J. Fontecha, C. Pelaez, M. Juarez, T. Requena, C. Gomez, M. Ramos, Biochemical and microbiological characteristics of Artisanal hard goat's cheese, J. Dairy Sci. 73 (1990) 1150-1157.

[16] R. Foshino, A. Invernizzi, R. Barucco, K. Stradiotto, Microbial composition, including incidence of pathogens, of a goat milk from bergamo region of Italy during a lactation year, J. Dairy Res. 69 (2002) 213-225.

[17] I. Groth, P. Schumann, K. Martin, B. Schuetze, K. Augsten, I. Kramer, E. Stackebrandt, Ornithinicoccus hortensis gen. Nov., sp. Nov., a soil actinomycete which contains L-ornithine, Int. J. Syst. Bacteriol. 49 (1999) $1717-1724$.

[18] M. Hatzikamari, E. Litopoulou-Tzanetaki, N. Tzanetakis, Microbiological characteristics of Anevato: a traditional Greek cheese, J. Appl. Microbiol. 87 (1999) 595-601.

[19] P.J. Jooste, C.J. Hugo, The taxonomy, ecology and cultivation of bacterial genera belonging to the family Flavobacteriaceae, Int. J. Food Microbiol. 53 (1999) 81-94.

[20] C.P. Kurtzman, J.W. Fell, The Yeasts: A Taxonomic Study, fourth ed., Elsevier Science, Amsterdam, 1998.

[21] J.K. Kyozaire, C.M. Veary, I.M. Petzer, E.F. Donkin, Microbiological quality of goat's milk obtained under different production systems, J. S. Afr. Vet. Assoc. 76 (2005) 69-73.

[22] E. Litopoulou-Tzanetaki, N. Tzanetakis, Microbial study of white brined cheese made from raw goat's milk, Food Microbiol. 9 (1992) 13-19.

[23] H.K. Lee, J. Chun, E.Y. Moon, S.H. Ko, D.S. Lee, H.S. Lee, K.S. Bae, Hahella chejuensis gen. Nov., sp. Nov., an extracellular-polysaccharide-producing marine bacterium, Int. J. Syst. Evol. Microbiol. 51 (2001) 661-666.

[24] G. Leitner, U. Merin, N. Silanikove, E. Ezra, M. Chaffer, N. Gollop, M. Winkler, A. Glickman, A. Saran, Effect of subclinical intramammary infection on somatic cell counts, NAGase activity and gross composition of goats' milk, J. Dairy Res. 71 (2004) 311-315.

[25] F. Leriche, A. Bordessoules, K. Fayolle, R. Karoui, K. Laval, L. Leblanc, E. Dufour, Alteration of raw-milk cheese by Pseudomonas spp.: monitoring the sources of contamination using fluorescence spectroscopy and metabolic profiling, J. Microbiol. Met. 59 (2004) 33-41.

[26] M.A. Lopez, F. Javier zavala Diaz de la Serna, J. JanRoblero, J.M. Romero, C. Hernandez-Rodriguez, Phylogenetic analysis of a biofilm bacterial population in a water pipeline in the Gulf of Mexico, FEMS Microbiol. Ecol. 58 (2006) 145-154.

[27] E. Manolopoulou, P. Sarantinopoulos, E. Zoidou, A. Aktypi, E. Moschopoulou, I. Kandarakis, E.M. Anifantakis, Evolution of microbial populations during 
traditional Feta cheese manufacture and ripening, Int. J. Food Microbiol. 82 (2003) 153-161.

[28] M. Mas, R. Tabla, J. Moriche, I. Roa, J. Gonzalez, J.E. Rebollo, P. Cáceres, Ibores goat's milk cheese: microbiological and physicochemical changes throughout ripening, Lait 82 (2002) 579-587.

[29] M. Medina, P. Gaya, M. Nunz, Gredos goat's milk cheese: microbiological and chemical changes throughout ripening, J. Dairy Res. 59 (1992) 563-566.

[30] L. Millet, M. Saubusse, R. Didienne, L. Tessier, M.C. Montel, Control of Listeria monocytogenes in raw-milk cheeses, Int. J. Food Microbiol. 108 (2006) 105-114.

[31] M. Morea, F. Baruzzi, P.S. Cocconcelli, Molecular and physiological characterization of dominant populations in traditional Mozzarella cheese processing, J. Appl. Microbiol. 87 (1999) 574-582.

[32] M. Mor-Mur, C. Carretero, R. Pla, B. Guamis, Microbiological changes during ripening of Cendrat del Montsec, a goat's milk cheese, Food Microbiol. 11 (1994) 177-185.

[33] P. Moroni, G. Pisoni, M. Antonini, G. ruffo, S. Carli, G. Varisco, P. Boettcher, Subclinical mastitis and antimicrobial susceptibility of Staphylococcus caprae and Staphylococcus epidermidis isolated from two Italian goat herds, J. Dairy Sci. 88 (2005) 1694-1704.

[34] J.E. Muehlherr, C. Zweifel, S. Corti, J.E. Blanco, R. Stephan, Microbiological quality of raw goat's and ewe's bulk-tank milk in Switzerland, J. Dairy Sci. 86 (2003) 3849-3856.

[35] D. Oppong, S.D. Bryant, R. Rangarajan, S. Steele, D. Radwell, L. Hyllengren, Application of molecular techniques to identify bacteria isolated from the leather industry, J. Am. Leath. Chem. Assoc. 101 (2006) 40-144.

[36] M.B. Pisano, M. Elisabetta Fadda, M. Deplano, A. Corda, S. cosentino, Microbiological and chemical characterization of Fiore Sardo, a traditional Sardinian cheese made from ewe's milk, Int. J. Dairy Technol. 59 (2006) 171-179.

[37] L. Psoni, N. Tzanetakis, E. Litopoulou-Tzanetaki, Microbiological characteristics of Batzos, a traditional Greek cheese from raw goat's milk, Food Microbiol. 20 (2003) 575-582.

[38] M. Rosario Corbo, R. Lanciotti, M. Albenzio, M. Sinigaglia, Occurrence and characterization of yeasts isolated from milks and dairy products of Apulia region, Int. J. Food Microbiol. 69 (2001) 147-152.

[39] S. Sablé, V. Portrait, V. Gautier, F. Letellier, G. Cottenceau, Microbiological changes in a soft raw goat's milk cheese during ripening, Enz. Microbiol. Technol. 21 (1997) 212-220.

[40] C. Sanchez-porro, S. Martin, E. Mellado, A. Ventosa, Diversity of moderately halophilic bacteria producing extracellular hydrolytic enzymes, J. Appl. Microbiol. 94 (2002) 295-300.

[41] K. Soryal, F.A. beyene, S. Zeng, B. Bah, K. Tesfai, Effect of goat breed and milk composition on yield, sensory quality, fatty acid concentration of soft cheese during lactation, Small Rum. Res. 58 (2005) 275-281.

[42] M.E. Tornadijo, J.M. Fresno, A. Bernardo, R.M. Martin-Sarmiento, J. Carballo, Microbial changes throughout the manufacturing and ripening of a Spanish goat's milk cheese (Armada variety), Lait 75 (1995) 551-570.

[43] M.E. Tornadijo, J.M. Fresno, J. Carballo, R.M. Sarmiento, Population levels, species and characteristics of micrococcaceae during the manufacturing and ripening of Armada-Sobado hard goat's milk cheese, J. Food Prot. 59 (1996) 1200-1207.

[44] M.E. Tornadijo, J.M. Fresno, R.M. Sarmiento, J. Carballo, Study of the yeasts during the ripening process of Armada cheeses from raw goat's milk, Lait 78 (1998) 647-659.

[45] M.E. Tornadijo, M.C. Garcia, J.M. Fresno, J. Carballo, Study of enterobacteriaceae during the manufacture and ripening of san Simon cheese, Food Microbiol. 18 (2001) 45-51.

[46] C. Vernozy-Rozand, C. Mazuy, G. Perrin, F. Haond, M. Bes, Y. Brun, J. Fleurette, Identification of micrococcaceae isolated from goat's milk and cheese in the PoitouCharentes region, Int. J. Food Microbiol. 30 (1996) 373-378.

[47] J.H. Yoon, K.C. Lee, N. Weiss, K.H. Kang, Y.H. Park, Jeotgalicoccus halotolerans gen. Nov., sp nov and Jeotgalicoccus psychrophilus sp nov., isolated from the traditional Korean fermented seafood jeotgal, Int. J. Syst. Evol. Microbiol. 53 (2003) 595-602.

[48] V. Zarate, F. Belda, C. Pérez, E. Cardell, Changes in the microbial flora of Tenerife goats' milk cheese during ripening, Int. Dairy J. 7 (1997) 635-641.

[49] A. Zlotkin, A. Eldar, C. Ghittino, H. Bercovier, Identification of Lactococcus garvieae by PCR, J. Clin. Microbiol. (1997) 983-985.

[50] E. Zumstein, R. Moletta, J.J. Godon, Examination of two years of community dynamics in an anaerobic bioreactor using fluorescence polymerase chain reaction (PCR) single-strand conformation polymorphism analysis, Environ. Microbiol. 2 (2000) 69-78. 